\title{
Applying the fear-avoidance model to the chronic whiplash syndrome
}

Citation for published version (APA):

Vangronsveld, K. L. H., Peters, M., Linton, S., Vlaeyen, J. W. S., \& Goossens, M. (2007). Applying the fear-avoidance model to the chronic whiplash syndrome. Pain, 130, 258-261.

https://doi.org/10.1016/j.pain.2007.04.015

Document status and date:

Published: 01/01/2007

DOI:

10.1016/j.pain.2007.04.015

Document Version:

Publisher's PDF, also known as Version of record

\section{Document license:}

Taverne

\section{Please check the document version of this publication:}

- A submitted manuscript is the version of the article upon submission and before peer-review. There can be important differences between the submitted version and the official published version of record.

People interested in the research are advised to contact the author for the final version of the publication, or visit the DOI to the publisher's website.

- The final author version and the galley proof are versions of the publication after peer review.

- The final published version features the final layout of the paper including the volume, issue and page numbers.

Link to publication

\footnotetext{
General rights rights.

- You may freely distribute the URL identifying the publication in the public portal. please follow below link for the End User Agreement:

www.umlib.nl/taverne-license

Take down policy

If you believe that this document breaches copyright please contact us at:

repository@maastrichtuniversity.nl

providing details and we will investigate your claim.
}

Copyright and moral rights for the publications made accessible in the public portal are retained by the authors and/or other copyright owners and it is a condition of accessing publications that users recognise and abide by the legal requirements associated with these

- Users may download and print one copy of any publication from the public portal for the purpose of private study or research.

- You may not further distribute the material or use it for any profit-making activity or commercial gain

If the publication is distributed under the terms of Article $25 \mathrm{fa}$ of the Dutch Copyright Act, indicated by the "Taverne" license above, 


\title{
Applying the fear-avoidance model to the chronic whiplash syndrome
}

\author{
Karoline Vangronsveld ${ }^{\mathrm{a}, *}$, Madelon Peters ${ }^{\mathrm{a}}$, Mariëlle Goossens ${ }^{\mathrm{a}}$, Steven Linton ${ }^{\mathrm{b}}$, \\ Johan Vlaeyen ${ }^{\text {a,c }}$ \\ ${ }^{a}$ Department of Medical, Clinical and Experimental Psychology, Maastricht University, P.O. Box 616, 6200 MD Maastricht, The Netherlands \\ ${ }^{\mathrm{b}}$ Department of Behavioural, Social and Legal Sciences, Orebro University, Sweden \\ ${ }^{\mathrm{c}}$ Department of Psychology, University of Leuven, Belgium
}

Received 13 January 2007; received in revised form 11 April 2007; accepted 11 April 2007

\section{Whiplash: the debate}

During a rear-end collision, the impact on the driver results in a backward and forward head movement that is similar to the crack of a whip and thus this often painful problem has been termed "whiplash". A striking pattern of complaints often occurs after the accident, characterized by neck pain, headache, visual disturbances, dizziness, muscle weakness, parasthesia, concentration difficulties, amnesia, and negative mood. The proportion of persons who develop chronic complaints after an acute whiplash injury varies considerably across studies, with figures ranging from $0 \%$ to $50 \%$ (Berglund et al., 2000; Olsson et al., 2002; Sterner et al., 2003).

So far, the available studies have not found conclusive evidence that biomedical factors contribute to the persistence of complaints after acute whiplash injury. Some researchers investigated the hypothesis that the complaints after a motor vehicle accident might be a result of injury to the neck musculature or cerebral injury. However, these studies have yielded inconsistent results (Ronnen et al., 1996; Wilmink and Patijn, 2001; Rodriquez et al., 2004; Nederhand et al., 2006). Often the hypothesized lesions or injuries are not supported by objective (f)MRI findings or other imaging techniques (Ronnen et al., 1996; Wilmink and Patijn, 2001). Moreover, there appears to be no relationship

\footnotetext{
${ }^{*}$ Corresponding author. Tel.: +31 43 3881613; fax: +31 433884155 . E-mail address: k.vangronsveld@dmkep.unimaas.nl (K. Vangronsveld).
}

between the extent of objectively assessed lesions or injuries and the degree of pain, disability or other symptoms reported by patients (Rodriquez et al., 2004). Finally, studies investigating pathophysiology have mainly been performed in patients with chronic complaints, and therefore conclusions regarding the predictive value of the observed injuries should be made with great caution.

Based on the clinical manifestations of the complaints the Quebec Task Force introduced the WAD classification (Spitzer et al., 1995). It was assumed that classifying people on the basis of the severity of somatic symptoms in the acute phase would be predictive of the persistence of complaints. Some studies indeed found that the WAD classification predicts time to recovery (Hartling et al., 2001; Suissa et al., 2001). However, this classification is based on the subjective complaints of patients and not on objective examination. At best, these studies show that initial elevated levels of complaints are the best predictor for bad outcome, but lack information on putative mechanisms involved.

Because of the lack of predictive value of somatic variables, researchers have begun to examine the role of cognitive, affective and behavioural factors in the transition from acute whiplash injury to chronic whiplash syndrome. It is well established that psychological factors are related to the transition from acute to chronic pain and disability in patients with chronic back pain (Linton, 2005). Two systematic reviews have evaluated the evidence that psychological factors may be involved in the transition from acute to chronic WAD (Côté et al., 2001; Scholten-Peeters et al., 2003). Both 
reviews concluded that there is only limited evidence for the prognostic role of psychological variables. However, this may be largely due to the heterogeneity of the predictor variables in the studies reviewed, precluding firm conclusions about specific psychological factors. Clearly there is a need for more standardization in research and a common theoretical framework.

\section{A theoretical framework}

The lack of consistent findings underscores the need for a new approach for evaluating research on prognostic factors for chronic whiplash syndrome. We argue that the fear-avoidance model (FA-model) may be a promising model for understanding the development of persistent complaints after an acute whiplash injury. The FA-model presents possible pathways by which injured patients might be "trapped" in a downward spiral of increasing avoidance, disability and pain. In essence, individuals with extreme negative thoughts about the harmfulness of pain (pain catastrophizing) are likely to develop fear of pain for events and situations that they associate with pain. This fear initiates avoidance behaviour and hypervigilance that can have short term pain reducing effects, but paradoxically, contributes to physical deconditioning and increased disability over a longer period of time. Increased disability may in turn reinforce further pain experiences, negative thoughts and avoidance behaviour. This model has proven to be successful in predicting persistence of chronic pain and disability in patients after an acute back pain episode (Boersma and Linton, 2006), and in predicting the inception of a new back pain episode in the general population (Linton, 2005; Severeijns et al., 2005). Similarly, catastrophizing and pain-related fear may be predictive of the persistence of neck pain after acute whiplash injury.

From a research standpoint, studying the recovery from acute whiplash injury is a very suitable paradigm to establish the prognostic value of the FA-model, since there is a clearly marked point in time for the onset of complaints, allowing for truly prospective designs. Moreover, it may be speculated that fear-avoidance beliefs are especially salient in patients with an acute and traumatic origin of complaints, because this may strengthen the belief that pain arises from physical injury and signifies harm to the body. Indeed, a study including back pain and neck pain patients with either acute or gradual onset pain George et al. (2001) found that patients with acute onset pain showed elevated levels of fear-avoidance beliefs compared to patients with gradual onset pain.

\section{Review of relevant studies}

Only a limited number of studies have examined whether the FA-model can be applied to the chronic whiplash syndrome. Nederhand et al. (2004) used the
Tampa Scale of Kinesiophobia (TSK) to measure pain-related fear and found this to be predictive for the development of chronic whiplash syndrome. The combination of high acute pain and high pain-related fear one week after the accident predicted disability at 6-months follow-up.

However, recently Buitenhuis et al. (2006) found mixed results for the role of pain-related fear in the development of chronic whiplash syndrome. Cross-sectional analyses showed that pain-related fear measured with the TSK was significantly related to pain intensity, concentration problems and difficulties in falling asleep at baseline. Moreover, survival analyses indicated that pain-related fear at baseline was a significant predictor of duration of complaints. However, when analyses were repeated with the inclusion of several somatic variables, the predictive value of TSK was no longer significant.

Another prospective cohort study by Sterling et al. could neither establish the predictive value of painrelated fear for the persistence of acute complaints. Although first analyses of their data suggested that TSK measured at baseline was elevated for those individuals who had not recovered at 6 months, their more definite analyses of the same data showed that TSK was not predictive (Sterling et al., 2003, 2005).

Other studies investigated the role of pain catastrophizing in relation to pain and disability following motor vehicle accidents. In one cross-sectional study pain catastrophizing was associated with higher levels of perceived pain intensity and perceived disability in patients with chronic whiplash syndrome, independent of levels of depression and anxiety (Sullivan et al., 1998). So far, no study has yet considered pain catastrophizing as a predictor for the transition from acute whiplash injury to chronic whiplash syndrome. There is, however, a recent study providing indirect evidence for a role of pain catastrophizing in the development of chronic whiplash syndrome. Caroll et al. (2006) investigated the relationship between active and passive coping and recovery in patients with acute whiplash injury. The results showed that a passive coping style was associated with less recovery at 12 months follow-up. Looking at the specific items that constituted the measure of passive coping, it is notable that these show considerable overlap with items assessing pain catastrophizing (Caroll et al., 2006).

Indirect evidence for the validity of the FA-model also comes from clinical studies. Cognitive-behavioural interventions that promote physical activity have been quite effective in decreasing pain and disability in patients with chronic whiplash syndrome and were found to lead to faster return to work in patients with acute whiplash complaints (Vendrig et al., 2000; Söderlund and Lindberg, 2001). Moreover, we recently demonstrated that in patients with chronic whiplash 
syndrome who were selected on the basis of the presence of high levels of pain-related fear, an exposure in vivo treatment led to major improvements in disability and pain (De Jong et al., submitted). In an exposure in vivo treatment the patient is gradually exposed to feared movements or activities. The patient learns that after performing the feared activity, the negative consequences such as increases in pain or re-injury fail to occur or will be less than expected. Exposure in vivo treatment was found to be very effective in reducing pain and disability in chronic back pain patients with high levels of pain-related fear (Vlaeyen et al., 2002) and our first small-scale study in patients with chronic whiplash syndrome revealed that this treatment is equally effective for these patients. Thus, the clinical evidence, though quite preliminary, suggests that reducing painrelated fear and pain catastrophizing results in improvements. This indirectly supports the idea that fear of pain is an important mechanism maintaining pain and disability.

\section{Conclusion and implications}

Although the evidence for the prognostic role of pain catastrophizing and pain-related fear is limited and not always consistent, we conclude that the FA-model is an interesting model that may bear fruit in future research initiatives. To substantiate whether indeed fear-avoidance beliefs are predictive of the prognosis of complaints after acute whiplash injury, additional longitudinal research is needed. This research should make multiple assessments in time of relevant predictor, outcome and mediating variables as this will provide information about the temporal precedence of changes in predictor and outcome variables and on the potential mediators of the association between predictor and outcome. For instance, it could be examined whether high levels of catastrophizing shortly after sustaining a whiplash trauma would lead to more complaints at final follow-up through an increase (or lack of decrease) of pain-related fear during the intermediate assessment period. In addition, the inclusion of a comprehensive set of predictor variables from both the fear-avoidance model as well as from competing models would create the possibility to compare the predictive utility of the variables from these alternative models. An example of a competing model would be the post-traumatic stress model. High comorbidity of chronic whiplash syndrome and complaints of Post-traumatic Stress Disorder (PTSD) have been reported. Although PTSD symptoms tend to be elevated in patients with various chronic pain conditions, this seems to be especially the case in patients with chronic pain after a motor vehicle accident (Mayou, 1992; Ursano et al., 1999). Asmundson et al. (2002) have argued that the high comorbidity of chronic pain and PTSD can be traced back to a shared vulnera- bility, namely a high level of anxiety sensitivity (i.e. the fear of anxiety related sensations). Furthermore, because of high symptom overlap between chronic pain and PTSD and the traumatic origin of complaints in this specific population initial levels of post-traumatic stress may have additional or better predictive power in comparison to fear-avoidance variables. Indeed, Sterling et al. (2005) found that elevated scores on the Impact of Event Scale (IES) in patients with acute whiplash injury were a better predictor of complaints at follow-up than pain-related fear. Thus, the inclusion of other potential predictors such as anxiety sensitivity and acute traumatic stress symptoms in future research is warranted.

Finally, future research should include multiple outcome measures. Patients after an acute whiplash injury are not only more prone to develop high levels of pain and disability, but they are also at risk to develop mood disorders (Sullivan et al., 2002), cognitive complaints (Bosma and Kessels, 2002), and as discussed above, post-traumatic stress disorder. Different predictors may emerge for these different outcome variables.

We conclude that the FA-model may offer a novel framework to explain the transition from acute whiplash injury to chronic whiplash syndrome. The FA-model may give direction for future research. This research should focus on comprehensive assessment of the various concepts in the FA-model as well as of concepts related to alternative models, and multiple outcome measures should be included. More information on the factors of influence on the transition form acute to chronic neck pain after a motor vehicle accident may provide tools for screening of patients at risk in the acute stage and enhance the development of treatment strategies for patients with both acute and chronic pain. Finally, the model is flexible in the sense that additional factors, specific for this patient population, may be added and be tested for their shared vulnerability and mutual maintenance.

\section{References}

Asmundson GJG, Coons MJ, Taylor S, Katz J. PTSD and the experience of pain: research and clinical implications of shared vulnerability and mutual maintenance models. Can J Psych 2002;47:930-7.

Berglund A, Alfredsson L, Cassidy JD, Jensen I, Nygren $\AA$. The association between exposure to a rear-end collision and future neck or shoulder pain: a cohort study. J Clin Epidemiol 2000;53:1089-94.

Boersma K, Linton SJ. Expectancy, fear and pain, in the prediction of chronic pain and disability: a prospective analysis. Eur J Pain 2006; 10:551-7.

Bosma FK, Kessels RPC. Cognitive impairments, psychological dysfunction and coping styles in patients with chronic whiplash syndrome. Neuropsych, Neuropsychol Behav Neurol 2002;15:56-65.

Buitenhuis J, Jaspers JPC, Vaclav F. Can Kinesiophobia predict the duration of neck symptoms in acute whiplash? Clin J Pain 2006;22:272-7. 
Caroll LJ, Cassidy JD, Côté P. The role of pain coping strategies in prognosis after whiplash injury: passive coping predicts slowed recovery. Pain 2006;124:18-26.

Côté P, Cassidy JD, Carroll L, Frank JW, Bombardier C. A systematic review of the prognosis of acute whiplash and a new conceptual framework to synthesize the literature. Spine 2001;26:E445-58.

George SZ, Fritz JM, Erhard RE. A comparison of fear-avoidance beliefs in patients with lumbar spine pain and cervical spine pain. Spine 2001;26:2139-45.

Hartling L, Brison RJ, Ardern C, Pickett W. Prognostic value of the Quebec classification of whiplash-associated disorders. Spine 2001;26:36-41.

Linton SJ. Do psychological factors increase the risk for back pain in the general population in both a cross-sectional and prospective analysis? Eur J Pain 2005;9:355-61.

Mayou R. Psychiatric aspects of road traffic accidents. Int Rev Psych 1992;4:45-54

Nederhand MJ, Hermens HJ, Ijzerman MJ, Groothuis KGM, Turk DC. The effect of fear of movement on muscle activation in posttraumatic neck pain disability. Clin J Pain 2006;22:519-25.

Nederhand MJ, Ijzerman MJ, Hermens H, Zilvold G. Predictive value of fear-avoidance in developing chronic neck pain disability: consequences for clinical decision making. Arch Phys Med Rehabil 2004;85:496-501.

Olsson I, Bunketorp O, Carlsson SG, STyf J. Prediction of outcome in whiplash-associated disorders using west Haven-Yale multidimensional pain inventory. Clin J Pain 2002;18:238-44.

Rodriquez AA, Barr KP, Burns SP. Whiplash: pathophysiology, diagnosis, treatment, and prognosis. Muscle Nerv 2004;29:768-81.

Ronnen HR, de Korte PJ, Brink PRG, van der Bijl HJ, Tonino AJ, Franke CL. Acute whiplash injury: is there a role for MR Imaging? A prospective study of 100 patients. Radiology 1996;201:93-6.

Scholten-Peeters GGM, Verhagen AP, Bekkering GE, van der Wint DAWM, Barnsley L, Oostendorp RAB, Hendriks EJM. Prognostic factors of whiplash-associated disorders: a systematic review of prospective cohort studies. Pain 2003;104:303-22.

Severeijns R, Vlaeyen JWS, Van den Hout MA, Picavet HSJ. Pain catastrophizing and consequences of musculoskeletal pain: a prospective study in the Dutch community. J Pain 2005;6:125-32.
Söderlund A, Lindberg P. An integrated physiotherapy/cognitive behavioral approach to the analysis and treatment of chronic Whiplash Associated Disorders, WAD. Disabil Rehabil 2001;23:436-47.

Spitzer WO, Skovron ML, Salmi LR, Cassidy JD, Duranceau J, Suissa S, Zeiss E. Scientific monograph of the Quebec task force on whiplash-associated disorders: redefining "whiplash" and its management. Spine 1995;20:1S-73S.

Sterling M, Jull G, Vicenzino B, Kenardy J, Darnell R. Physical and psychological factors predict outcome following whiplash injury. Pain 2005;114:141-8.

Sterling M, Kenardy J, Jull G, Vicenzino B. The development of psychological changes following whiplash injury. Pain 2003;106:481-9.

Sterner Y, Toolanen G, Gerdle B, Hildingson C. The incidence of whiplash trauma and the effects of different factors on recovery. $\mathbf{J}$ Spinal Disord Tech 2003;16:195-9.

Suissa S, Harder S, Veilleux M. The relation between initial symptoms and signs and the prognosis of whiplash. Eur Spine J 2001;10:44-9.

Sullivan MJL, Stanish W, Sullivan ME, Tripp D. Differential predictors of pain and disability in patients with whiplash injuries. Pain Res Manag 2002;7:68-74.

Sullivan MJL, Stanish W, Waite H, Sullivan M, Tripp DA. Catastrophizing, pain and disability in patients with soft-tissue injuries. Pain 1998;77:253-60.

Ursano RJ, Fullerton CS, Epstein RS, Crowley B, Kao T-C, Vance K, Craig KJ, Dougall AL, Baum A. Acute and chronic posttraumatic stress disorder in motor vehicle accident victims. Am J Psych 1999;156:589-95.

Vendrig AA, van Akkerveeken PF, McWhorter KR. Results of a multimodal treatment program for patients with chronic symptoms after a whiplash injury of the neck. Spine 2000;25:238-44.

Vlaeyen JWS, de Jong J, Geilen M, Heuts PHTG, van Breukelen G. The treatment of fear of movement/(re)injury in chronic low back pain - further evidence on the effectiveness of exposure in vivo. Clin J Pain 2002;18:251-61.

Wilmink JT, Patijn J. MR imaging of alar ligament in whiplashassociated disorders: an observer study. Neuroradiology 2001;43:859-63. 